KOŚCIÓŁ I PRAWO 10(23) 2021, nr 1, s. 227-237

DOI: http://dx.doi.org/10.18290/kip21101-12

\author{
Pablo de la Fuente de Pablo \\ Cezary Taracha
}

\title{
"UNDER THE PACIFYING ARMS OF THE CROSS." THE VALLEY OF THE FALLEN: A PLACE \\ OF IMPRISONMENT, RECONCILIATION AND SOCIAL REINTEGRATION IN SPAIN (1940-1959)
}

\begin{abstract}
INTRODUCTION
El Valle de los Caídos or the Valley of the Fallen is a monumental memorial, a Catholic basilica and Benedictine abbey at Cuelgamuros Valley in Guadarrama Hills, near Madrid. The monument was designed by Pedro Muguruza and Diego Méndez in the vein of reviving Juan de Herrera's architecture [Méndez 1982]. The basilica is also a national graveyard of 33 . 833 people who fought on both sides of the Spanish Civil War, 1936-1939. ${ }^{1}$

The site covers the area of $13.6 \mathrm{~km}^{2}$ of pinewoods and granite boulders on Guadarrama Hills, more than $900 \mathrm{~m}$ above sea-level. The most valuable architectural feature is an impressive 150-metre-high Christian cross, the tallest in the world.
\end{abstract}

DR. PABlo de la Fuente de PABlo - Department of Hispanic World, Politics and International Relationships, Faculty of Humanities, the John Paul II Catholic University of Lublin; correspondence address: Al. Racławickie 14, 20-950 Lublin, Poland; e-mail: pablo.de-la-fuente-de-pablo@kul.pl; https://orcid.org/0000-0002-5893-2308

Dr. habil. Cezary Taracha, University Professor - Department of Hispanic World, Politics and International Relationships, Faculty of Humanities, the John Paul II Catholic University of Lublin; correspondence address: Al. Racławickie 14, 20-950 Lublin, Poland; e-mail: cezary.taracha@kul.pl; https://orcid.org/ 0000-0001-8613-9078

${ }^{1}$ See: Listado enterrados Valle de los Caídos. Datos actualizados el 12 de abril de 2021, https://www.epdata.es/datos/listado-enterrados-valle-caidos/137 [accessed: 30.04.2021]. 


\section{THE ROAD TO PEACE, MERCY AND FORGIVENESS}

Many of those who have turned their bitterness against the monument to this day have emphasised the vindictive and revenge-driven character of the monument, invoking the decree of 1 April 1940 of the Presidency of the Government. This decree, signed by General Franco, is explicit: "For those purposes a secluded place will be chosen where a great temple for our dead will be erected, in which those who have fallen while serving God and the Country will be prayed for throughout the centuries."

The signing of the decree on the first anniversary of the end of the Spanish Civil War is no coincidence. One of the main features of this war was the persecution of Christians, to such an extent that in the view of the events, the Catholic Church declared it a crusade [De la Fuente de Pablo 2019]. It is clear that, a year after the hurricane of hatred and violence that had ravished the country, the wounds were still open. It is true that the Valley of the Fallen was conceived as a memorial for those who died in defence of Catholic and traditional Spain. However, 17 years later, the paradigm had changed. The legal provision establishing the foundation of the Holy Cross of the Valley of the Fallen is telling and explicit: "The grandiose Cross that presides over and inspires the Monument [of the Valley of the Fallen] imbues this achievement with a profoundly Christian character. For this reason, the sacred duty of honouring our heroes and martyrs must always be accompanied by the feeling of forgiveness that the Gospel message imposes. Moreover, the decades of peace that have followed the Victory have seen the development of a policy guided by the highest sense of unity and brotherhood among Spaniards. This must be, therefore, the Monument to all the Fallen, over whose sacrifice the peaceloving arms of the Cross triumph."

In other words, 18 years after the end of the civil war, following the spirit of peace, mercy and forgiveness that was spreading among Span-

\footnotetext{
${ }^{2}$ Presidencia del Gobierno, Decreto de 1 de abril de 1940 disponiendo se alcen Basílica, Monasterio y Cuartel de Juventudes, en la finca situada en las vertientes de la Sierra del Guadarrama (El Escorial), conocida por Cuelga-muros [sic], para perpetuar la memoria de los caídos en nuestra Gloriosa Cruzada, "Boletín Oficial de Estado" (02.04.1940), p. 2240.

${ }^{3}$ Jefatura del Estado, Decreto-ley de 23 de agosto de 1957 por el que se establece la Fundación de la Santa Cruz del Valle de los Caídos, "Boletín Oficial de Estado" (05.09.1957), p. 834.
} 
iards, the monument was opened, two years before its inauguration, to house the corpses of all Spaniards, regardless of the side on which they had fought. Together, Nationalists and Republicans enjoy eternal rest in the columbaria buried in the basilica under the pacifying arms of the largest cross in the world.

The main objective of this article is to shed more light on the correctional facility that supplied part of the workforce with a major focus on its unquestionable role in the social reintegration of the prisoners, and to present the facts that dispel the black legend surrounding the monument built to reconcile the Spaniards [Cué 2012, 11].

\section{THE VALLEY OF THE FALLEN: A FORCED LABOUR CAMP?}

Many anti-Christian authors have underlined this fact, which will be refuted in this work, of the "original sin of the Valley of the Fallen:" the myth of the 20,000 forced prisoners in a mausoleum in honour of Francisco Franco [Sueiro 1976, 67; Olmeda 2019, 48; Rubio 2011, 206; Moreno $2016,104]$.

Although the figure of 20,000 forced labourers is the most illustrative example of communist propaganda - a lie is a revolutionary weapon that becomes the truth when repeated over and over again - historian Alberto Bárcena, professor at the CEU-San Pablo University in Madrid, has demonstrated on the basis of primary sources that the number of people who worked on the site during its construction was around 3,000, approximately half of whom were free labourers [Bárcena 2012, 706].

An extremely important aspect is that although there were people serving prison sentences, none of them could be considered as forced, as they voluntarily requested their entry into this social reintegration programme. In other words, the prisoner had to apply for it. An application had to be made to the authorities of the Patronato de Nuestra Señora de la Merced, a body of the Ministry of Justice which was created for this purpose and which recalls the traditional work performed centuries ago by the Mercedarians who were helping people in captivity [Blanco 2009, 111-40]. In addition to filling in a form, they had to write a statement expressing their willingness to join the works. Professor Bárcena has even found some cases of prisoners who used family influences to oust other prisoners and join 
the programme in their place. The most paradigmatic case was undoubtedly that of the historian Nicolás Sánchez-Albornoz, who later became a professor at the universities of New York, Columbia and Yale, who has not denied that he managed to work as a prisoner in the Valley of the Fallen thanks to the pressure exerted by his influential family. SánchezAlbornoz was one of the few prisoners who escaped the works and who, in an undoubtedly picturesque manner, arrived on foot at the neighbouring municipality of El Escorial without any impediment and was picked up by a car waiting there [Bárcena 2012, 624].

Despite all the lies that have been told and continue to be told about the Valley of the Fallen, the social reintegration provided by this programme offered major advantages: 1) the redemption of sentences, given that at the beginning working one day equalled to serving two days of sentence. This coefficient was gradually increased to two additional days of redemption per day worked, then to three, and then to six additional days of redemption per day worked. In other words, people sentenced for twenty or thirty years of prison for serious crimes could leave after working four or five years in the Valley of the Fallen. This led many prisoners in Spain to voluntarily apply for the programme [ibid, 702]; 2) in addition to the shortened sentences, the prisoners received a salary for their work that was exactly the same, given their professional category, as that of the staff who were not serving a sentence. The conditions were the same for both: equal working rights, medical care, working hours, etc. [ibid., 453$68]$; 3) another advantage of the convicts was that they could accommodate their families in the existing housing for workers [ibid., 711-13].

Professor Bárcena's work has clearly demonstrated the existing benefits which explain why so many prisoners requested to work in the construction of the Valley of the Fallen. As a result, the number of applicants by far exceeded the number of the available jobs. In fact, one of the punishments that existed in the disciplinary regime of the programme was that in the case of misbehaviour, the inmate was expulsed from the programme and had to return to the prison where he was prior to his arrival at the construction site. This was the most severe punishment a prisoner could be subjected to in case of misbehaviour and it well explains why there was only prisoner riot during the entire time of the construction [ibid., 603]. 
Yet another advantage related to the work in the Valley of the Fallen and a very interesting topic is the summer camp for prisoners' relatives. There were two kinds of relatives that need to be taken into consideration and distinguished between i.e.: the direct relatives who lived with the prisoners all year round, and other relatives who visited them during the summer months of July and August. The archival documentation obtained by Professor Bárcena reveals the immense amount of bureaucratic work involved in these procedures [ibid., 585]. In order to understand it, let us have a look at the example of the prisoner Juan Solomando who was working in a grocery shop and who in the summer of 1950 was visited by four different groups of relatives [ibid., 589-93]. What is even more interesting is that Solomando had a nephew who was in his permanent foster care because of difficult economic situation of the boy's parents. Juan Solomando's nephew was enrolled in the school attended by the children of the people working at the construction site both prisoners and free employees. Another case worth mentioning is that of another convict - Gonzalo de Córdoba - who arrived at the Valley of the Fallen to teach at this school and who, at the end of his sentence, continued to teach there as a free man [ibid., 603-10]. Some of his students completed university studies which was a major social and professional achievement in the Spain of 1940s and 1950s. To give but an example, inmate Mr Orejas who came to the Valley of the Fallen to work as a male nurse at the medical dispensary there had a son who went to the aforementioned school. The boy continued his studies and finally obtained a university degree in architecture. After graduation, he began working at Huarte, the main construction company that built the Valley of the Fallen [ibid., 608].

\section{HOW IS MYTH FABRICATED?}

The lie-infested and yet very successful wheel of propaganda aimed at discrediting the construction of the Valley of the Fallen was immediately set in motion [Sueiro 1976; Lafuente 2002; Torres 2006; Rubio 2011; Calleja 2018; Olmeda 2019]. Indalecio Prieto the socialist leader who was one of the men responsible for the bolshevisation of the party and the outbreak of the civil war in 1936 described the Valley as pharaonic works built with the blood of slaves [Bárcena 2012, 97]. The imagery was swiftly 
picked up and used by the Marxist parties to attack the regime of general Franco. Many books were published on the topic and some of their authors went even so far as to speak of an extermination camp. An example of that kind of literature can be Rafael Torres [2006] who wrote a book entitled "Los esclavos de Franco" ("Franco's Slaves") or "Esclavos por la patria" ("Slaves for the Fatherland") by Lafuente [2002]. As it has turned out, the propaganda has been very effective in conveying the image and convincing the public that the manipulated information was the truth. Due to that, dispelling the legend has been an extremely difficult task. One of the greatest achievements of Professor Bárcena is that his work clearly shows the way to dismantle this myth piece by piece.

A major historiographical problem related to the study of the Valley of the Fallen is not that the reality has been exaggerated, but that it has been invented altogether. The best way to verify the lies is to look for primary sources of information and check the reality against the propaganda. To dispel the myth let us have a look at one of the aspects frequently mentioned in relation to the construction of the Valley i.e. the work-related accidents. According to the "common knowledge" there were thousands of accidents at work that resulted in death. In order to establish the course of the true events, Professor Bárcena has conducted a thorough study of the available primary sources. The study has revealed that the first fatality in the construction of the Valley of the Fallen was Alberto Pérez Alonso who died in 1948 i.e. nearly eight years after the work had started [ibid., 636-39]. Professor Bárcena has been able to establish this fact on the basis of the information regarding the victim. The victim's widow - Jerónima Díaz Organista, who worked as a cook in the Valley of the Fallen - asked for social housing in Madrid when the construction works were completed, and in her application stated that her husband was the first person to die in a work-related accident at the site. Applying for social housing was common among the people working in the Valley or their families. Upon completing their sentence or the construction, whichever came first, many of the workers, both those who had come as free people or were prisoners, were granted social housing in Madrid where they usually emigrated in search of a new job. One of the best known cases was that of a prisoner Justo Roldán Sainero, who was better known under the nickname of "Matacuras" ("priest killer") [ibid., 680-96]. He owed his nickname to the fact that during the civil war he had murdered five priests in the territory 
governed by the republicans. He was sentenced to death for three of those assassinations. Later, the sentence was changed to 30 years of imprisonment. He applied to the programme and was freed after seven years of working in the Valley of the Fallen. The story of the "Matacuras" is also an example of the social rehabilitation that enabled the full reintegration of the man in the society. Thanks to the environment which fostered forgiveness and reconciliation, Justo Roldán Sainero was able to work as a janitor of the community of Benedictine monks of the Holy Cross of the Valley of the Fallen. In other words, the former murderer of priests was endowed with all the keys to the abbey's premises. It is worth observing that the Board of Works considered that given his background this position was not suitable for "Matacuras" and ordered him to be transfered to another job within the building. However, the monks themselves protected him, and Justo Roldán Sainero remained in his post, despite the Board's disapproval. The above described conditions were a fact in 1950, when a general pardon was granted to all prisoners, nine years before the inauguration of the monument. It needs to be underlined that the majority of the pardoned prisoners remained at the site and continued their work as freemen there. Apart from the teacher and the male nurse who stayed at the site, there was also the case of doctor Lausín who arrived as a prisoner and continued in the same post after completing his sentence, which is particularly noteworthy.

\section{THE EXTERMINATION CAMP HOAX}

The relations between the wardens and the prisoners can be best described on the example of the most violent incident that occurred during construction, when a corporal of the Guardia Civil slapped one of the inmates because of a personal dispute they were having. As a result, the Guardia Civil was transferred to the Island of Menorca. It is true that, nowadays, this Mediterranean island is the destination of many Europeans who choose to spend their holidays there, but in those days, before the tourist boom, it was considered to be an exile [ibid., 576-77].

I have already mentioned the peculiar escape of a prominent prisoner, which can only be explained by the lax security. It can be quite a shock to realise that the convicts would go out on Sundays to dance or to see a film 
in the cinema in neighbouring towns such as San Lorenzo del Escorial or Guadarrama. The only condition was that they had to promise to return at a given time. As a result, there are cases of marriages between prisoners and girls from these neighbouring towns.

Another example of the privileges enjoyed by the prisoners was the anecdotic event that took place on Christmas Eve. One of the prisoners prepared a traditional dinner and invited two wardens who belonged to the Guardia Civil force to celebrate this important occasion. However, the prisoner insisted that the wardens could not enter his home with firearms. Finally, the wardens decided to leave their weapons at another prisoner's house asking him to keep them till they came back. After that they went to the dinner, and spent the entire night together: prisoners and guards, drinking and dancing as to the tunes of the accordion played by one of the family members [ibid., 577].

Another aspect which makes the work of Professor Bárcena stand out is the information on the repeated complaints of the construction companies regarding the cost of the food supplied for the workers, both free and convicted as their diet was exactly the same. Another bone of contention were the amendments to legislation regarding social conditions that applied to all workers regardless of their penal situation, which led to unsuccessful threats to resign from the contract if the amendments were introduced.

The fact that best dispels the lies fabricated by the leftist and antiChristian propaganda is the accident rate. Contrary to the popular belief, out of the 3,000 people working at the site over nearly two decades, only 15 died as a result of accidents at work [Linares and Manrique 2011, 35]. Unlike the unreliable accounts, this number is taken from the first-aid post at the construction site run by Dr. Causín and the nurse Orejas, both of whom arrived at the Valley as prisoners and who continued in the same job when they were released. Among those fatalities there was a young worker who repeatedly refused to tie his safety harness when working at height and who ended up tragically falling from a scaffolding. Another victim died at the site in a traffic accident. He climbed on the back of a lorry transporting materials and was thrown out of the lorry at a sharp turn. 


\section{CONCLUSION: THE TRUTH WILL SET YOU FREE}

There is nothing better than to end this work by paraphrasing the Gospel of Saint John (8:32), and dispelling the body of lies that have mounted around the Valley of the Fallen which some rather biased media present as Franco's mausoleum. It is true that the remains of the General were buried in the basilica on 23 November 1975 and exhumed on 24 October 2019 in a ritual that evoked Masonic connotations. However, it is hard to accept that General Francisco Franco had the idea of turning the monument into his own mausoleum since he left no instructions in his will as to where he was to be buried. Moreover, among the tens of thousands of deceased who rest there, he is the only one who did not die during the Spanish Civil War. It was precisely one of the first decisions taken after the restoration of the monarchy.

Questioning the first relevant decision of King Juan Carlos I started the polemics that led to the desecration of the tomb of his predecessor. The work was carefully planned and carried out by a social-communist government which, among other things, aims at ending the constitutional monarchy. What better way to do it than by questioning its legitimacy?

\section{REFERENCES}

Bárcena, Alberto. 2012. "La redención de penas en el Valle de los Caídos.” Ph.D. dissertation. Universidad C.E.U. San Pablo.

Blanco, Juan. 2009. Valle de los Caídos, ni presos políticos, ni trabajos forzados. Madrid: FN.

Calleja, José María. 2018. El Valle de los Caídos. Madrid: Ed. Espasa Calpe.

Cué. Ramón. 2012. El Valle de los Caídos. Reconciliación de España. Madrid: Plataforma 2003.

De la Fuente de Pablo, Pablo. 2019. "An x-ray of a genocide: persecution of Catholic Church during the Spanish Civil War (1936-1939).” Teka Komisji Historycznej 1 (16):45-56. Doi: 10.18290/teka.2019.5

Lafuente, Isaías. 2002. Esclavos por la patria. Madrid: Temas de Hoy.

Linares Clemente, Pablo and José María Manrique García. 2011. El Valle de los Caídos. Crónica de una persecución salvaje. Valladolid: Galland Books.

Méndez, Diego. 1982. El Valle de los Caídos: idea, proyecto y construcción. Madrid: Fundación Nacional Francisco Franco.

Moreno Garrido, Belén. 2016. "Medios, imágenes y memoria: el Valle de los Caídos.” Ph.D. dissertation. Universidad Complutense de Madrid. 
Olmeda, Fernando. 2019. El Valle de los Caídos. Una memoria de España. Barcelona: Península.

Rubio, Tàrio, ed. 2011. El Valle de los Caídos y la represión franquista. Tarragona: Arola. Sueiro, Daniel. 1976. La verdadera historia del Valle de los Caídos. Madrid: Sedmay.

Torres, Rafael. 2006. Los esclavos de Franco. Madrid: Oberon.

\author{
"Under the Pacifying Arms of the Cross." \\ The Valley of the Fallen: \\ a Place of Imprisonment, Reconciliation and Social Reintegration in Spain \\ (1940-1959)
}

Summary

The Valley of the Fallen is the monument that boasts the largest Christian cross in the world. Buried at its feet are tens of thousands of those who fought and fell during the Spanish Civil War (1936-1939). They rest in the Basilica of the Holy Cross together without any designation as to on which side they fought. The article focuses on the vicissitudes of the penitentiary colony made up mainly of Republican prisoners sentenced for serious crimes committed during the war. This monument, a symbol of atonement and reconciliation, has become the target of a relentless political onslaught carried out by the socialist and communist government and fuelled by a series of myths analysed in the article.

Keywords: Spain; Valley of the Fallen; reconciliation; social reintegration

\author{
„Utuleni w ramionach Krzyża”. \\ Dolina Poległych - miejsce uwięzienia, pojednania i reintegracji \\ w społeczeństwie hiszpańskim (1940-1959)
}

Streszczenie

Dolina Poległych (Valle de los Caídos) to monumentalne założenie, mauzoleum, szczycące się posiadaniem największego chrześcijańskiego krzyża w świecie. U jego stóp spoczywają dziesiątki tysięcy żołnierzy, którzy walczyli i polegli w czasie Hiszpańskiej Wojny Domowej (1936-1039). Są oni pochowani w bazylice Świętego Krzyża razem, bez określania przynależności do którejkolwiek ze stron konfliktu. Artykuł niniejszy koncentruje się na losach kolonii więziennej, składającej się w większości z republikańskich wieźniów skazanych za przestępstwa, w części przypadków bardzo krwawe, popełnione w trakcie trwania wojny. Wspomniane mauzoleum, symbol wybaczenia i pojednania, stało się w ostatnich czasach przedmiotem nieustających ataków ze strony obecnego lewicowego rządu (socjaliści i komuniści), opierających się na serii mitów, które są przedmiotem analizy w niniejszym artykule.

Słowa kluczowe: Hiszpania; Dolina Poległych; pojednanie; reintegracja społeczna 
Informacje o Autorze: DR PABLO DE LA FUENTE DE PABLO - Katedra Świata Hiszpańskiego, Polityki i Relacji Międzynarodowych, Wydział Nauk Humanistycznych, Katolicki Uniwersytet Lubelski Jana Pawła II; adres do korespondencji: Al. Racławickie 14, 20-950 Lublin, Polska; e-mail: pablo.de-la-fuente-de-pablo@kul.pl; https://orcid.org/0000-0002-5893-2308

Informacje o Autorze: DR HAB. CEZARY TARACHA, PROF. KUL - Katedra Świata Hiszpańskiego, Polityki i Relacji Międzynarodowych, Wydział Nauk Humanistycznych, Katolicki Uniwersytet Lubelski Jana Pawła II; adres do korespondencji: Al. Racławickie 14, 20-950 Lublin, Polska; e-mail: cezary.taracha@kul.pl; https:// orcid.org/0000-0001-8613-9078 